\title{
Combination chemotherapy of gemcitabine and vinorelbine for pretreated non-small- cell lung cancer: a retrospective study
}

This article was published in the following Dove Press journal:

Lung Cancer: Targets and Therapy

25 September 2015

Number of times this article has been viewed

\section{Seigo Minami \\ Yoshitaka Ogata \\ Suguru Yamamoto \\ Kiyoshi Komuta}

Department of Respiratory Medicine, Osaka Police Hospital, Osaka, Japan

Correspondence: Seigo Minami Department of Respiratory Medicine, Osaka Police Hospital, 10-3I Kitayamacho, Tennoji-ku, Osaka-City,

Osaka 543-0035, Japan

$\mathrm{Tel}+8 \mathrm{I} 6677 \mid 605$ I

Fax +8I 6 677| 2838

Email seigominami@oph.gr.jp
Background: Advanced non-small-cell lung cancer (NSCLC) eventually progresses after first-line chemotherapy, and usually requires salvage treatment. Although neither gemcitabine nor vinorelbine is approved as a candidate drug in the second- or further-line for NSCLC, they can be alternative drugs in terms of anti-tumor effects and toxicities. Actually, in our institution, we often use a combination of these two anti-tumor drugs in our daily practice.

Methods: We retrospectively reviewed 85 patients with advanced NSCLC who had received combination chemotherapy of gemcitabine and vinorelbine after a platinum-based regimen from June 2007 to June 2014 in Osaka Police Hospital, and performed Cox proportional hazard analyses in order to detect predictive factors for progression-free survival (PFS).

Results: Patient characteristics included a mean age of 65.5 years, 56 males, 54 adenocarcinoma, 53 European Clinical Oncology Group performance status 0-1. Thirteen and 35 patients received the study treatment as the second- and third-line treatment, respectively. The overall response rate, disease control rate, PFS, and overall survival were 4.7\% (95\% confidence interval 1.3\%-11.6\%), 30.6\% (21.0\%-41.5\%), 2.1 months (1.7-2.8 months), and 6.9 months (5.0-11.0 months). Twenty-one and six patients experienced grade 4 neutropenia and febrile neutropenia, respectively. European Clinical Oncology Group performance status 0-1 was detected as a factor predicting longer PFS by univariate (hazard ratio, 1.63; 95\% confidence interval, 1.28-2.08; $P<0.001)$ and multivariate $(1.65,1.27-2.14, P<0.001)$ analyses.

Conclusion: This combination was ineffective and harmful to pretreated patients with NSCLC. We do not recommend this regimen as a later-line treatment option.

Keywords: gemcitabine, vinorelbine, non-small cell lung cancer, performance status, retrospective study, combination chemotherapy

\section{Introduction}

The majority of non-small-cell lung cancer (NSCLC) is already inoperable at the time of diagnosis and requires systemic chemotherapy. However, almost all patients with advanced NSCLC eventually experience disease progression even after standard platinum-based chemotherapy. Only $69 \%, 38 \%$, and $18 \%$ of patients received the second-, third-, and fourth-line chemotherapy in a Japanese cancer center. ${ }^{1}$ Currently, three anti-tumor drugs: docetaxel, ${ }^{2}$ pemetrexed, ${ }^{3}$ and erlotinib, ${ }^{4}$ have been pivotal options for second-line regimens. Unfortunately, monotherapy using any of these agents has provided only around $10 \%$ response. Moreover, no regimen has been recognized as an established third- or further-line regimen.

Gemcitabine and vinorelbine are a pyrimidine antimetabolite and a semi-synthetic vinca alkaloid drug, respectively. Owing to their cytotoxic effects and mild toxicities, 
these two drugs as monotherapy have been approved as a standard regimen for chemo-naïve elderly patients with advanced NSCLC. ${ }^{5,6}$ On the other hand, combination of these two drugs also showed favorable efficacy and tolerability in many Phase II and III trials for untreated and pretreated NSCLC patients, around the year 2000. There were two Italian Phase III trials that focused on chemo-naïve elderly patients aged $\geq 70$ years. ${ }^{6,7}$ Combination of gemcitabine and vinorelbine was less effective and more toxic than the two drugs given singly in one study, ${ }^{6}$ but successfully provided longer survival and delayed deterioration of symptoms and quality-of-life than vinorelbine monotherapy in the other study. ${ }^{7,8}$ There were also two Phase III trials that had compared this combination regimen with platinum-based and vinorelbine-containing regimens in the first-line setting. ${ }^{9,10}$ The combination of gemcitabine and vinorelbine failed to show significant survival advantage compared with platinum-based regimens. Based on these results, we have often used this combination regimen in our daily practice for progressive NSCLC after a platinum-based regimen.

The aim of our study was to retrospectively evaluate combination chemotherapy of gemcitabine and vinorelbine for pretreated patients with NSCLC.

Table I Patient characteristics $(\mathrm{N}=85)$

\begin{tabular}{|c|c|}
\hline \multicolumn{2}{|l|}{ Age, years } \\
\hline Mean $\pm S D$ & $65.5 \pm 9.7$ \\
\hline \multicolumn{2}{|l|}{ Sex } \\
\hline Male/female & $56 / 29$ \\
\hline \multicolumn{2}{|l|}{ Histology } \\
\hline $\mathrm{Ad} / \mathrm{Sq} /$ others & $54 / 23 / 8$ \\
\hline \multicolumn{2}{|l|}{ Staging } \\
\hline III/IV/post-surgical recurrence & $20 / 58 / 7$ \\
\hline \multicolumn{2}{|l|}{ Distant metastases } \\
\hline Brain metastasis & 25 \\
\hline Bone metastasis & 15 \\
\hline Liver metastasis & 13 \\
\hline Intra-pulmonary or pleural metastasis & 38 \\
\hline \multicolumn{2}{|l|}{ ECOG performance status } \\
\hline $0-1 / 2 / 3$ & $53 / 24 / 8$ \\
\hline \multicolumn{2}{|l|}{ EGFR mutation status } \\
\hline Positive/wild-type/not evaluated & $9 / 42 / 34$ \\
\hline \multicolumn{2}{|l|}{ Number of prior regimens } \\
\hline$|/ 2| \geq 3$ & $13 / 35 / 37$ \\
\hline Median (range) & $2(1-6)$ \\
\hline \multicolumn{2}{|l|}{ Prior anti-tumor drugs } \\
\hline Carboplatin & $82^{a}$ \\
\hline Cisplatin & $5^{\mathrm{a}}$ \\
\hline Docetaxel & 38 \\
\hline EGFR-TKI & 38 \\
\hline Pemetrexed & 26 \\
\hline
\end{tabular}

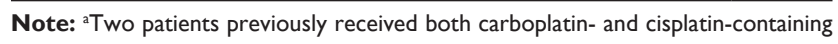
regimens.

Abbreviations: Ad, adenocarcinoma; ECOG, European Clinical Oncology Group; $\mathrm{SD}$, standard deviation; Sq, squamous cell carcinoma; TKI, tyrosine-kinase inhibitor.
Table 2 Treatment $(\mathrm{N}=85)$

\begin{tabular}{ll}
\hline $\begin{array}{l}\text { Number of delivered courses } \\
I / 2 / 3 / 4 / \geq 5\end{array}$ & $20 / 20 / 12 / 16 / 17$ \\
Mean $\pm \mathrm{SD}$ & $3.1 \pm 1.9$ \\
Discontinuation reasons $(\mathrm{N})$ & 56 \\
Progressive disease & 13 \\
Deteriorated conditions & 9 \\
Completion of $4-8$ courses & 3 \\
Complicated diseases & 3 \\
Adverse effects & 1 \\
Lost to follow-up & \\
Initial dose intensity $(\%)$, mean $\pm S D$ & $80.9 \pm 14.0$ \\
Gemcitabine $\left(I, 000 \mathrm{mg} / \mathrm{m}^{2}\right)$ & $80.7 \pm 15.2$ \\
Vinorelbine $\left(25 \mathrm{mg} / \mathrm{m}^{2}\right)$ & \\
Total dose intensity $(\%)$, mean $\pm \mathrm{SD}$ & $66.8 \pm 16.8$ \\
Gemcitabine & $67.3 \pm 18.0$ \\
Vinorelbine & \\
\hline
\end{tabular}

Abbreviation: SD, standard deviation.

\section{Methods}

\section{Patient selection and experimental design}

The study was carried out at the Osaka Police Hospital. We retrospectively reviewed the medical records and collected data on patients who met all of the following criteria: 1) histologically or cytologically confirmed NSCLC; 2) stage III/IV or post-surgical recurrence; 3 ) disease progression after first or further-line chemotherapy, including platinum-based regimen; 4) patients who had received combination chemotherapy of gemcitabine and vinorelbine from June 2007 to June 2014 at our institution. The data collected from all of the patient medical records included the following: sex; age; histological type; European Clinical Oncology Group (ECOG) performance status (PS); distant metastases; EGFR mutation status; prior and post-treatment regimens; progression-free survival (PFS), and overall survival (OS) from the start of the combination regimen; efficacy; treatment schedule and adverse effects. The Osaka Police Hospital ethics committee approved this study and waived the requirement for informed consent (approval number 106).

Table 3 Post-protocol chemotherapy

\begin{tabular}{ll}
\hline Number of regimens & \\
$0 / I / 2 / \geq 3$ & $32 / 27 / 14 / 12$ \\
Median (range) & $\mathrm{I}(0-10)$ \\
Anti-tumor drugs & \\
EGFR-TKI & 25 \\
S-I & 21 \\
Docetaxel & 13 \\
CPT-II & 13 \\
Pemetrexed & 7 \\
Gemcitabine & 4 \\
\hline
\end{tabular}

Abbreviations: CPT-II, irinotecan; S-I, oral 5-fluorouracil derivative consisting tegafur, gimeracil and oteracil potassium; TKI, tyrosine-kinase inhibitor. 
Table 4 Efficacy $(\mathrm{N}=85)$

\begin{tabular}{lll}
\hline Efficacy & $\begin{array}{l}\text { All } \\
(\mathbf{N}=\mathbf{8 5})\end{array}$ & $\begin{array}{l}\text { Third- or further- } \\
\text { line } \mathbf{( N = 7 2 )}\end{array}$ \\
\hline Complete response $(\mathrm{N})$ & 0 & 0 \\
Partial response $(\mathrm{N})$ & 4 & 4 \\
Stable disease $(\mathrm{N})$ & 22 & 20 \\
Progressive disease $(\mathrm{N})$ & 48 & $4 \mathrm{I}$ \\
Not evaluated $(\mathrm{N})$ & $\mathrm{II}$ & 7 \\
Overall response rate $(95 \% \mathrm{Cl})(\%)$ & $4.7(\mathrm{I} .3-\mathrm{II} .6)$ & $5.6(\mathrm{I} .5-13.6)$ \\
Disease control rate $(95 \% \mathrm{Cl})(\%)$ & $30.6(21.0-41.5)$ & $33.3(22.7-45.4)$ \\
\hline
\end{tabular}

Abbreviation: $\mathrm{Cl}$, confidence interval.

\section{Treatment plan}

As a rule, gemcitabine $\left(1,000 \mathrm{mg} / \mathrm{m}^{2}\right.$, day 1 and 8$)$ and vinorelbine $\left(25 \mathrm{mg} / \mathrm{m}^{2}\right.$, day 1 and 8$)$ were administered intravenously every 3 weeks. Although chemotherapeutic course was not defined, treatment was discontinued at the time of disease progression, unacceptable toxicity, or withdrawal of consent.
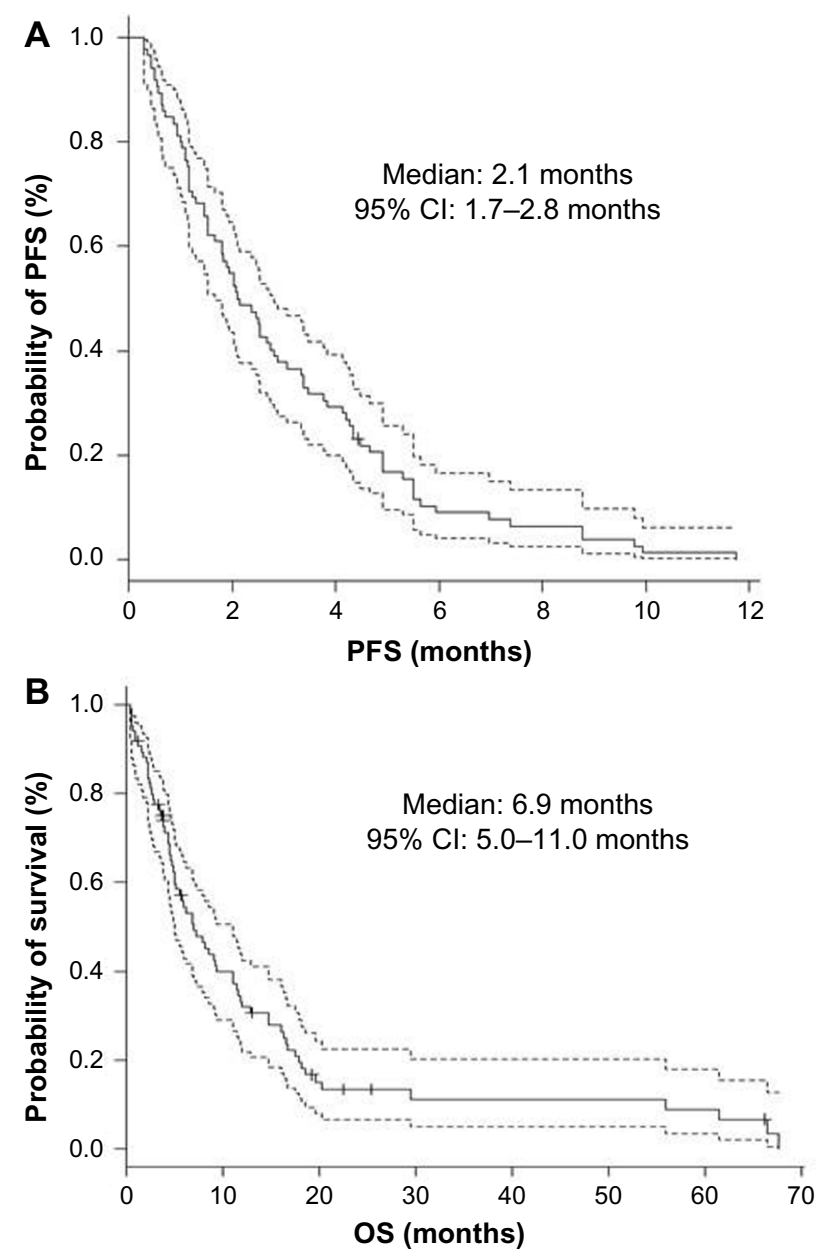

Figure I Kaplan-Meier curves (solid line) of all participants ( $\mathrm{N}=85$ ).

Notes: (A) Progression-free survival (PFS); and (B) overall survival (OS) of gemcitabine and vinorelbine treatment with $95 \%$ confidence band (dashed lines). Abbreviation: $\mathrm{Cl}$, confidence interval.

\section{Assessments}

Required baseline assessments included, at least, chest and abdominal computed tomography (CT) within 1 month before treatment. Response was evaluated according to RECIST version 1.1. ${ }^{11}$ Toxicity was graded by the National Cancer Institute-Common Terminology Criteria for Adverse Events version 4.0. ${ }^{12}$

The evaluable population for overall response included all patients, defined as those who had received at least one cycle chemotherapy and had at least two response assessments over 6 weeks after the introduction unless objective progressive disease was determined. Patients who received the study therapy were considered evaluable for PFS, OS, and safety. PFS and OS were evaluated by Kaplan-Meier method.

\section{Data analysis}

The data for normally distributed continuous variables, discrete variables, and categorical variables were expressed
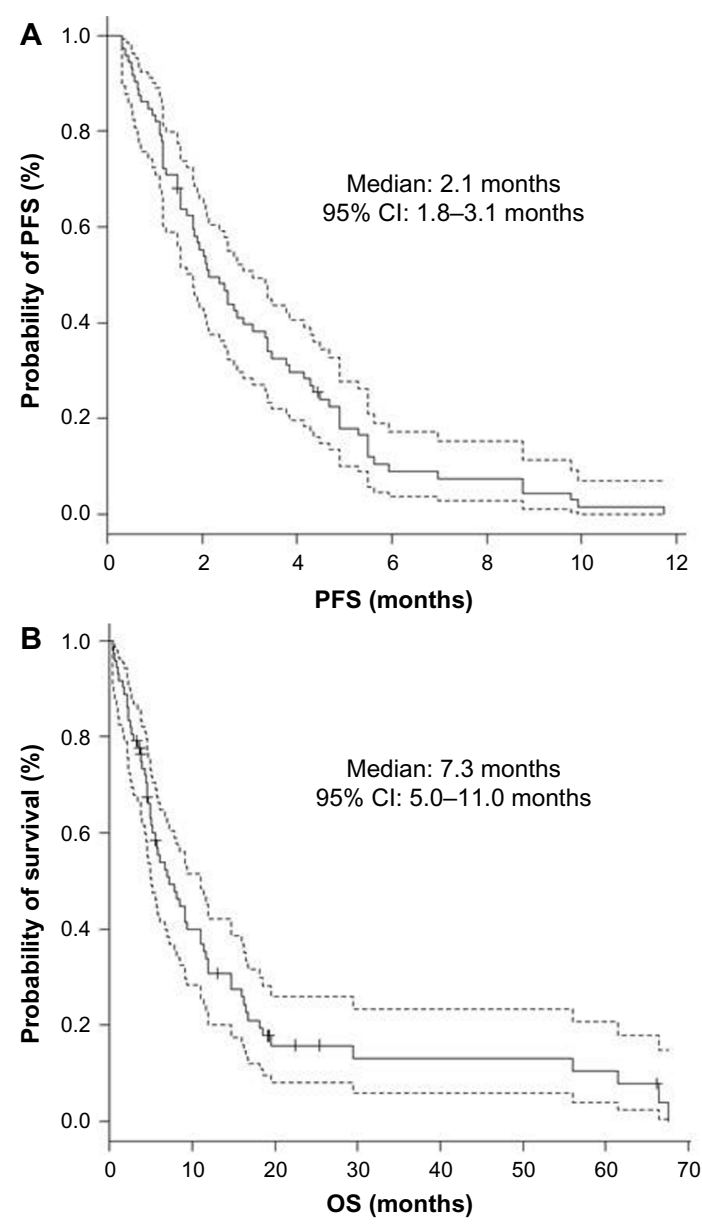

Figure 2 Kaplan-Meier curves (solid line) of third- and further-line chemotherapy $(\mathrm{N}=72)$.

Notes: (A) Progression-free survival (PFS); and (B) overall survival (OS) of gemcitabine and vinorelbine treatment with $95 \%$ confidence band (dashed lines). Abbreviation: $\mathrm{Cl}$, confidence interval. 
Table 5 Adverse effects $(\mathrm{N}=85)$

\begin{tabular}{lllll}
\hline & Grade & & & \\
\cline { 2 - 4 } & I & 2 & 3 & $\mathbf{4}$ \\
\hline Hematological (N) & & & & \\
Leukopenia & 13 & 20 & 23 & 8 \\
Neutropenia & $1 \mathrm{I}$ & 4 & 25 & 21 \\
Hemoglobin decrease & 22 & $4 \mathrm{I}$ & 17 & 0 \\
Thrombocytopenia & 21 & 24 & $1 \mathrm{I}$ & 0 \\
Non-hematological (N) & & & & \\
Aminotransferase increase & 40 & 5 & 2 & 0 \\
Serum creatinine increase & 6 & 0 & 0 & 0 \\
Febrile neutropenia & 0 & 0 & 6 & 0 \\
Anorexia & 38 & 13 & 11 & 0 \\
Nausea or vomiting & 16 & 7 & 0 & 0 \\
Fatigue & 20 & 11 & 1 & 0 \\
Constipation & 21 & 23 & 4 & 0 \\
Diarrhea & 12 & 1 & 0 & 0 \\
Oral mucositis & 6 & 4 & 0 & 0 \\
Vasculitis & 4 & 5 & 0 & 0 \\
Rash & 10 & 6 & 0 & 0 \\
Fever & 18 & 2 & 0 & 0 \\
\hline
\end{tabular}

as the mean \pm standard deviation, median (range), and frequency. To examine how patients' backgrounds influenced survival, the following seven background variables were added as an independent variable in the Cox proportional hazard regression model: ECOG PS, sex, age, histology, prior regimens, distant metastases, and initial dose reduction rate of gemcitabine. We excluded the initial dose reduction rate of vinorelbine as an independent variable because dose reductions of these two anti-tumor drugs were closely correlated. The results were evaluated in terms of the hazard ratio (HR) and 95\% confidence interval (CI). A $P$-value $<0.05$ was considered as being statistically significant.

All statistical analyses were performed with EZR (Saitama Medical Center, Jichi Medical University, Saitama, Japan), which is a graphical user interface for $\mathrm{R}$ (The $\mathrm{R}$ Foundation for Statistical Computing, Vienna, Austria). More precisely, it is a modified version of $\mathrm{R}$ commander designed to add statistical functions frequently used in

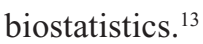

\section{Results}

During the study period, 88 patients received combination chemotherapy. Two patients received the study regimen as first-line chemotherapy. One patient had been treated only with EGFR-tyrosine-kinase inhibitors prior to the study regimen. Thus, these three patients were excluded from the analyses. As of March 31, 2015, all patients discontinued the study regimen, three were still alive and nine lost to followup. Patient baseline characteristics are shown in Table 1. Eight patients had ECOG PS of 3, and 37 patients received the study regimen in the fourth- or further-line setting. The study treatment administered is presented in Table 2 . The initial doses of gemcitabine and vinorelbine were reduced by physicians to less than 800 and $20 \mathrm{mg} / \mathrm{m}^{2}$ in 49 and 46 patients, respectively. Forty-two, 18 , and 38 patients required dose reduction after the second course, delay of the next course, and skipped administration of day 8, respectively. Table 3 describes post-protocol chemotherapy. The study regimen was the last chemotherapy in 32 patients.

Table 6 Univariate and multivariate Cox proportional hazard analysis of factors influencing progression-free survival ( $\mathrm{N}=85)$

\begin{tabular}{|c|c|c|c|c|c|c|}
\hline \multirow[t]{2}{*}{ Risk factors } & \multicolumn{3}{|c|}{ Univariate } & \multicolumn{3}{|c|}{ Multivariate } \\
\hline & HR & $95 \% \mathrm{Cl}$ & $P$ & HR & $95 \% \mathrm{Cl}$ & $P$ \\
\hline \multicolumn{7}{|l|}{ Age } \\
\hline$\geq 70$ years vs $<70$ years & 0.76 & $0.47-1.21$ & 0.24 & 0.70 & $0.43-1.13$ & 0.15 \\
\hline \multicolumn{7}{|l|}{ Sex } \\
\hline Male vs female & 1.19 & $0.75-1.89$ & 0.47 & 0.90 & $0.52-1.54$ & 0.69 \\
\hline \multicolumn{7}{|l|}{ ECOG PS } \\
\hline $2-3$ vs $0-1$ & 1.63 & $1.28-2.08$ & $<0.00$ I & 1.65 & $1.27-2.14$ & $<0.001$ \\
\hline \multicolumn{7}{|l|}{ Histology } \\
\hline Adenocarcinoma vs others & 0.66 & $0.42-1.04$ & 0.07 & 0.74 & $0.42-1.30$ & 0.29 \\
\hline \multicolumn{7}{|l|}{ Distant metastases } \\
\hline Yes vs no or not evaluated & 1.07 & $0.66-1.73$ & 0.80 & 1.34 & $0.76-2.38$ & 0.31 \\
\hline \multicolumn{7}{|l|}{ Number of prior regimens } \\
\hline$\geq 3$ vs $\mathrm{I}-2$ & 0.74 & $0.48-1.16$ & 0.19 & 0.76 & $0.46-1.27$ & 0.30 \\
\hline \multicolumn{7}{|c|}{ Gemcitabine initial dose reduction rate (\%) } \\
\hline$\geq 80 \%$ vs $<80 \%$ & 1.07 & $0.69-1.67$ & 0.76 & 0.95 & $0.60-1.50$ & 0.81 \\
\hline
\end{tabular}

Notes: Coded as I ( $\geq 70$ years, male, ECOG PS 2-3, adenocarcinoma histology, positive distant metastases, $\geq 3$ prior regimens, and initial gemcitabine dose of more than $80 \%$ ) and as 0 ( $<70$ years, female, ECOG PS 0-I, non-adenocarcinoma histology, I-2 prior regimens and initial gemcitabine dose of less than $80 \%$ ).

Abbreviations: $\mathrm{Cl}$, confidence interval; ECOG PS, European Clinical Oncology Group performance status; HR, hazard ratio. 
The overall response rate (RR), disease control rate, PFS, and OS of all 85 patients were $4.7 \%$ (95\% CI, $1.3 \%-11.6 \%$ ), $30.6 \%$ (21.0\%-41.5\%), 2.1 months (1.7-2.8 months), and 6.9 months (5.0-11.0 months), while those of 72 patients in the third- or further-line were $5.6 \%(1.5 \%-13.6 \%)$, $33.3 \%$ (22.7\%-45.4\%), 2.1 months (1.8-3.1 months), and 7.3 months (5.0-11.0 months), respectively (Table 4, Figures 1 and 2). All four patients who achieved partial response had received the study regimen as the third- or further-line treatment. Twenty-one and six patients suffered from grade 4 neutropenia and febrile neutropenia, respectively (Table 5). Seven patients died within a month after introduction of the study regimen. All of them initially had ECOG PS of 2 or 3, and consequently progressed or could not be evaluated owing to rapidly deteriorated symptoms. Both univariate and multivariate analyses detected ECOG PS $0-1$ as a factor predicting longer PFS (univariate; HR 1.63, 95\% CI 1.28-2.08, $P<0.001$, multivariate; HR 1.65 , 95\% CI 1.27-2.14, $P<0.001$ ) (Table 6).

\section{Discussion}

This was a retrospective study in practical use of combination regimen of gemcitabine and vinorelbine for patients with advanced NSCLC previously treated with platinum-based regimen.

Table 7 Review of prospective studies of combination chemotherapy of gemcitabine and vinorelbine for pretreated patients

\begin{tabular}{|c|c|c|c|c|c|c|c|}
\hline Authors (year) & $\mathbf{N}$ & Phase & Line & Dose and schedule & $\begin{array}{l}\text { RR } \\
\text { DCR }\end{array}$ & PFS & os \\
\hline \multirow[t]{3}{*}{ Camps et al $(2000)^{15}$} & 16 & Pilot & 2 nd & G I,200 mg/m² (Day I, 8, I5) & $6.25 \%$ & ND & $25 \mathrm{~W}$ \\
\hline & & & & V $25 \mathrm{mg} / \mathrm{m}^{2}$ (Day I, 8) & $37.5 \%$ & & \\
\hline & & & & Every 28 days, until PD & & & \\
\hline \multirow[t]{3}{*}{ Hainsworth et al $(2000)^{18}$} & 55 & II & 2nd & G I,000 mg/m² (Day I, 8, I5) & $18 \%$ & $5.0 \mathrm{M}^{\mathrm{a}}$ & $6.5 \mathrm{M}$ \\
\hline & & & & V 20 mg/m² (Day I, 8) & $66 \%$ & & \\
\hline & & & & Every 28 days & & & \\
\hline \multirow[t]{3}{*}{ Kosmas et al $(200 \mathrm{I})^{22}$} & 40 & ॥ & 2nd & G I,000 mg/m² (Day I, 8) & $22.5 \%$ & $4.5 \mathrm{M}$ & $7 M$ \\
\hline & & & & V $25 \mathrm{mg} / \mathrm{m}^{2}$ (Day I, 8) & $55 \%$ & & \\
\hline & & & & Every 21 days & & & \\
\hline \multirow[t]{3}{*}{ Pectasides et al $(200 \mathrm{I})^{24}$} & 39 & II & 2nd & G 800 mg/m² (Day I, 8) & $2.6 \%$ & $4.7 \mathrm{M}$ & $7.3 \mathrm{M}$ \\
\hline & & & & V 25 mg/m² (Day I, 8) & $64.1 \%$ & & \\
\hline & & & & Every 21 days & & & \\
\hline \multirow[t]{3}{*}{ Herbst et al $(2002)^{20}$} & 36 & II & 2nd or 3rd & G $900-1,000$ mg/m² (Day I, 8) & $17 \%$ & $4.6 \mathrm{M}$ & $8.5 \mathrm{M}$ \\
\hline & & & & V 25-30 mg/m² (Day I, 8) & $67 \%$ & & \\
\hline & & & & Every 21 days & & & \\
\hline \multirow[t]{3}{*}{ Chen et al $(2003)^{17}$} & 17 & II & $2 n d$ & G 800 mg/m² (Day I, 8, I5) & $31.3 \%$ & $4.6 \mathrm{M}$ & $8.3 \mathrm{M}$ \\
\hline & & & & V $20 \mathrm{mg} / \mathrm{m}^{2}$ (Day I, 8, I5) & $93.8 \%$ & & \\
\hline & & & & Every 28 days & & & \\
\hline \multirow[t]{3}{*}{ Park et al $(2004)^{23}$} & 38 & ॥ & 2 nd & G I,000 mg/m² (Day I, 8) & $21 \%$ & $3.9 \mathrm{M}$ & $8.1 \mathrm{M}$ \\
\hline & & & & V 30 mg/m² (Day I, 8) & $76 \%$ & & \\
\hline & & & & Every 21 days & & & \\
\hline \multirow[t]{3}{*}{ Ando et al $(2005)^{14}$} & 20 & I & $3 r d$ & G $600-1,000$ mg/m² (Day I, 8) & $0 \%$ & $3.9 \mathrm{M}$ & $6.8 \mathrm{M}$ \\
\hline & & & & V 20-25 mg/m² (Day I, 8) & $74 \%$ & & \\
\hline & & & & Every 21 days & & & \\
\hline \multirow[t]{3}{*}{ Juergens et al $(2007)^{21}$} & 15 & II & 2 nd & G I,000 mg/m² (Day I, I5) & $0 \%$ & $4.2 \mathrm{M}$ & $9.2 \mathrm{M}$ \\
\hline & & & & V 30 mg/m² (Day I, I5) & $73 \%$ & & \\
\hline & & & & Every 28 days, 6 cycles & & & \\
\hline \multirow[t]{3}{*}{ Han et al $(2008)^{19}$} & 40 & Ran II & 2 nd & G 900 mg/m² (Day I, 8) & $13 \%$ & $2.6 \mathrm{M}$ & ND \\
\hline & & & & V 25 mg/m² (Day I, 8) & $45 \%$ & & \\
\hline & & & & Every 21 days, until PD & & & \\
\hline \multirow[t]{3}{*}{ Chelis et al $(2010)^{16}$} & 14 & ॥ & 2 nd or & G I,200 mg/m² (Day I, I5) & $0 \%$ & $3 M$ & $4 M$ \\
\hline & & & further-line & V 30 mg/m² (Day I, I5) & $27 \%$ & & \\
\hline & & & setting & Every 28 days, 6 cycles & & & \\
\hline \multirow[t]{3}{*}{ Our study } & 85 & Retro & 2 nd or & G I,000 mg/m² (Day I, 8) & $4.7 \%$ & $2.1 \mathrm{M}$ & $6.9 \mathrm{M}$ \\
\hline & & & further-line & V $25 \mathrm{mg} / \mathrm{m}^{2}$ (Day I, 8) & $30.6 \%$ & & \\
\hline & & & setting & Every 21 days & & & \\
\hline
\end{tabular}

Note: ${ }^{\text {aPFS }}$ of patients with stable disease $\sim$ complete remission.

Abbreviations: DCR, disease control rate; G, gemcitabine; M, months; ND, not described; OS, overall survival; PD, progressive disease; PFS, progression-free survival; Ran, randomized; Retro, retrospective; RR, response rate; $V$, vinorelbine; $W$, weeks. 
The most important finding is that this combination regimen was not effective in response and survival benefit. Thus, we do not recommend this regimen for pretreated patients. Compared with the previous studies, ${ }^{14-24}$ our results were similar or inferior in overall RR and disease control rate, but had remarkably shorter PFS (Table 7). Contrary to these previous studies that focused on the second-line setting and enrolled patients with better PS, $85 \%$ and $9 \%$ of our patients were in the third- or further-line and had poor PS of 3, respectively. For chemotherapy-naïve patients, this combination regimen was not inferior in response and survival to platinum-based

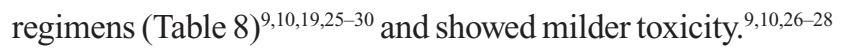
However, for patients with poor PS, ECOG PS 2, this combination regimen provided minimal effects and harmful toxicities similar to carboplatin plus paclitaxel. ${ }^{29}$ On the other hand, our results were opposite to the latest retrospective Korean study of 40 elderly patients (age $\geq 65$ years). Sixty percent of study participants were receiving third- or further-line treatment and 20\% had ECOG PS 2, and it was concluded that this combination is an effective and tolerable salvage regimen in elderly and heavily pretreated patients, based on their results of higher RR (34.5\%), longer PFS (3.1 months), and OS (10.3 months). ${ }^{31}$

The second important finding is that only PS at the time of introduction of this regimen was an influential predicting factor for survival. This result was consistent with the previous pooled analyses that detected poorer PS as one of the prognostic factors for survival, ${ }^{32-36}$ but different from them in that our analysis did not detect other parameters as predictive factors. Besides continued good PS, response to previous treatment is also suggested to be a predictor of benefit from third- and fourth-line chemotherapy. ${ }^{37}$ In addition, a longer interval between the first- and third-line chemotherapy was associated with longer OS after third-line chemotherapy. ${ }^{1}$ We could not obtain information during the first-line chemotherapy in eleven patients, whose past charts were lost or who had transferred to our institution after front-line chemotherapy. Therefore, we did not analyze response to previous treatment.

Our study includes the following three limitations: first, our study was a single institutional and retrospective study. Although our study may not be universal, our results discouraged the conducting of prospective studies of this

Table 8 Review of prospective studies comparing combination chemotherapy of gemcitabine and vinorelbine with platinum-based regimens

\begin{tabular}{|c|c|c|c|c|c|c|c|}
\hline Authors (year) & Phase & Line & $\mathbf{N}$ & Regimens & $\mathbf{R R}$ & PFS & os \\
\hline \multirow[t]{3}{*}{ Gridelli et al $(2003)^{10}$} & III & Ist & 251 & GV & $25 \%$ & $17 \mathrm{~W}$ & $32 \mathrm{~W}$ \\
\hline & & & 250 & $\mathrm{CDDP}+\mathrm{G}$ or $\mathrm{V}$ & $30 \%$ & $23 \mathrm{~W}$ & $38 \mathrm{~W}$ \\
\hline & & & & (Age $<70$ years) & $P=0.30$ & $P=0.004$ & $P=0.08$ \\
\hline \multirow[t]{3}{*}{ Laack et al $(2004)^{28}$} & III & Ist & 143 & GV & $13.0 \%$ & $19.3 \mathrm{~W}$ & $35.9 \mathrm{~W}$ \\
\hline & & & 144 & $\mathrm{CDDP}+\mathrm{GV}$ & $28.3 \%$ & $22.3 \mathrm{~W}$ & $32.4 \mathrm{~W}$ \\
\hline & & & & & $P=0.004$ & $P=0.35$ & $P=0.73$ \\
\hline \multirow[t]{3}{*}{ Chen et al $(2005)^{25}$} & Ran II & lst & 43 & GV & $23.3 \%$ & $4.1 \mathrm{M}$ & $9.5 \mathrm{M}$ \\
\hline & & & 43 & $\mathrm{CDDP}+\mathrm{GV}$ & $46.5 \%$ & $7.8 \mathrm{M}$ & $13.1 \mathrm{M}$ \\
\hline & & & & & $P=0.022$ & $P=0.206$ & $P=0.375$ \\
\hline \multirow[t]{3}{*}{ Esteban et al $(2006)^{26}$} & Ran II & lst & 57 & GV & $37 \%$ & $5.0 \mathrm{M}$ & $9 M$ \\
\hline & & & 57 & $\mathrm{CDDP}+\mathrm{GV}$ & $47 \%$ & $5.8 \mathrm{M}$ & $10 M$ \\
\hline & & & & & $P=0.5$ & $P=0.6$ & $P=0.9$ \\
\hline \multirow[t]{3}{*}{ Yamamoto et al $(2006)^{30}$} & Ran II & lst & 64 & GV & $21.0 \%$ & $137 \mathrm{D}$ & $385 \mathrm{D}$ \\
\hline & & & 64 & $\mathrm{CBDCA}+\mathrm{G}$ & $20.3 \%$ & $165 \mathrm{D}$ & $432 \mathrm{D}$ \\
\hline & & & & & $P=0.60$ & $P=0.676$ & $P=0.298$ \\
\hline \multirow[t]{3}{*}{ Greco et al $(2007)^{27}$} & $\| / / I I$ & Ist & 170 & GV & $24 \%$ & $3.9 \mathrm{M}$ & $10.7 \mathrm{M}$ \\
\hline & & & 167 & $\mathrm{CBDCA}+\mathrm{G}+\mathrm{PTX}$ & $25 \%$ & $6.0 \mathrm{M}$ & $10.3 \mathrm{M}$ \\
\hline & & & & & $P=N D$ & $P=0.324$ & $P=0.269$ \\
\hline \multirow[t]{3}{*}{ Han et al $(2008)^{19}$} & Ran II & Ist & 70 & GV & $26 \%$ & $4.6 \mathrm{M}$ & $13.1 \mathrm{M}$ \\
\hline & & & 75 & CDDP + CPT-II & $38 \%$ & $3.8 \mathrm{M}$ & $15.9 \mathrm{M}$ \\
\hline & & & & & $P=0.144$ & $P=0.415$ & $P=0.285$ \\
\hline \multirow[t]{3}{*}{ Flotten et al $(2012)^{9}$} & III & Ist & 215 & GV & ND & ND & $6.3 \mathrm{M}$ \\
\hline & & & 222 & $C B D C A+V$ & & & $7.0 \mathrm{M}$ \\
\hline & & & & & & & $P=0.802$ \\
\hline \multirow[t]{3}{*}{ Saito et al $(2012)^{29}$} & Ran II & Ist & 43 & GV & $20.9 \%$ & $2.7 \mathrm{M}$ & $6.0 \mathrm{M}$ \\
\hline & & & 41 & $\mathrm{CBDCA}+\mathrm{PTX}$ & $29.3 \%$ & $2.9 \mathrm{M}$ & $5.9 \mathrm{M}$ \\
\hline & & & & (ECOG PS 2) & $P=N D$ & $P=N D$ & $P=N D$ \\
\hline
\end{tabular}

Abbreviations: CBDCA, carboplatin; CDDP, cisplatin; CPT-II, irinotecan; D, days; ECOG PS, European Clinical Oncology Group performance status; G, gemcitabine; M, months; ND, not described; OS, overall survival; PFS, progression-free survival; PTX, paclitaxel; Ran, randomized; RR, response rate; V, vinorelbine; W, weeks. 
combination therapy for pretreated patients. Second, the lower initial dose and total dose intensity in our practice might reduce the potential efficacy of this combination therapy. Our mean initial dose of gemcitabine, approximately $800 \mathrm{mg} / \mathrm{m}^{2}$, was similar to the recommended dose in the previous Japanese Phase I study that evaluated this combination therapy in the third-line setting. ${ }^{14}$ Thus, our practical dose reduction might be negligible. Third, our sample size was small. Although RR varies among drugs, races and lines, the RRs of docetaxel, pemetrexed and erlotinib monotherapy for pretreated Japanese patients with NSCLC were $12.8 \%(\mathrm{~N}=187),{ }^{38} 18.5 \%(\mathrm{~N}=108),{ }^{39}$ and $28.3 \%(\mathrm{~N}=60),{ }^{40}$ respectively. Assuming an expected RR of $10 \%$ or $15 \%$ with a two-sided alpha of $5 \%$, our statistical power is $43 \%$ or $88 \%$, respectively. Fourth, there is no rationale supporting combination chemotherapy for third- or further-line NSCLC treatment. However, some oncologists dared to choose combination chemotherapy rather than monotherapy even in the third-line setting, ${ }^{41-43}$ possibly because monotherapy strategy is reasonable on the basis of evidences but is disappointing in efficacy. An established regimen supported by prospective studies is also necessary in the third- and further-line settings.

\section{Conclusion}

This combination was ineffective and harmful to pretreated patients with NSCLC. We do not recommend this regimen as the later-line option.

\section{Disclosure}

The authors report no conflicts of interest in this work.

\section{References}

1. Asahina H, Sekine I, Horinouchi H, et al. Retrospective analysis of third-line and fourth-line chemotherapy for advanced non-small-cell lung cancer. Clin Lung Cancer. 2012;13(1):39-43.

2. Shepherd FA, Dancey J, Ramlau R, et al. Prospective randomized trial of docetaxel versus best supportive care in patients with non-small-cell lung cancer previously treated with platinum-based chemotherapy. J Clin Oncol. 2000;18(10):2095-2103.

3. Hanna N, Shepherd FA, Fossella FV, et al. Randomized phase III trial of pemetrexed versus docetaxel in patients with non-small-cell lung cancer previously treated with chemotherapy. J Clin Oncol. 2004;22(9): 1589-1597.

4. Shepherd FA, Rodrigues Pereira J, Ciuleanu T, et al. Erlotinib in previously treated non-small-cell lung cancer. $N$ Engl J Med. 2005;353(2):123-132.

5. No authors listed. Effects of vinorelbine on quality of life and survival of elderly patients with advanced non-small-cell lung cancer. The Elderly Lung Cancer Vinorelbine Italian Study Group. J Natl Cancer Inst. 1999; 91(1):66-72.

6. Gridelli C, Perrone F, Gallo C, et al. Chemotherapy for elderly patients with advanced non-small-cell lung cancer: the Multicenter Italian Lung Cancer in the Elderly Study (MILES) phase III randomized trial. $J$ Natl Cancer Inst. 2003;95(5):362-372.
7. Frasci G, Lorusso V, Panza N, et al. Gemcitabine plus vinorelbine versus vinorelbine alone in elderly patients with advanced non-small-cell lung cancer. J Clin Oncol. 2000;18(13):2529-2536.

8. Frasci G, Lorusso V, Panza N, et al. Gemcitabine plus vinorelbine yields better survival outcome than vinorelbine alone in elderly patients with advanced non-small cell lung cancer. A Southern Italy Cooperative Oncology Group (SICOG) phase III trial. Lung Cancer. 2001;34 Suppl 4: S65-S69.

9. Flotten O, Gronberg BH, Bremnes R, et al. Vinorelbine and gemcitabine vs vinorelbine and carboplatin as first-line treatment of advanced NSCLC. A phase III randomised controlled trial by the Norwegian Lung Cancer Study Group. Br J Cancer. 2012;107(3):442-447.

10. Gridelli C, Gallo C, Shepherd FA, et al. Gemcitabine plus vinorelbine compared with cisplatin plus vinorelbine or cisplatin plus gemcitabine for advanced non-small-cell lung cancer: a phase III trial of the Italian GEMVIN Investigators and the National Cancer Institute of Canada Clinical Trials Group. J Clin Oncol. 2003;21(16):3025-3034.

11. Eisenhauer EA, Therasse P, Bogaerts J, et al. New response evaluation criteria in solid tumours: revised RECIST guideline (version 1.1). Eur J Cancer. Jan 2009;45(2):228-247.

12. National Cancer Institute, Cancer Therapy Evaluation Program, Protocol Development. Common Terminology Criteria for Adverse Events (CTCAE) v4.0. http://ctep.cancer.gov/protocolDevelopment/ electronic_applications/ctc.htm\#ctc_40. Accessed August 26, 2015.

13. Kanda Y. Investigation of the freely available easy-to-use software 'EZR' for medical statistics. Bone Marrow Transplant. 2013;48(3):452-458.

14. Ando S, Suzuki M, Iida T, Nakajima T, Kimura H. Phase I study of vinorelbine plus gemcitabine as third-line chemotherapy for refractory non-small cell lung cancer. Oncol Rep. 2005;14(3):689-694.

15. Camps C, Martinez EN, Jaime AB. Second-line treatment with gemcitabine and vinorelbine in non-small-cell lung cancer (NSCLC) cisplatin failures: a pilot study. Lung Cancer. 2000;27(1):47-53.

16. Chelis L, Xenidis N, Amarantidis K, et al. Biweekly vinorelbine and gemcitabine as second-line treatment and beyond in non-small cell lung cancer. Chemotherapy. 2010;56(5):353-358.

17. Chen YM, Perng RP, Lee CS, Lin WC, Tsai CM, Whang-Peng J. Phase II study of gemcitabine and vinorelbine combination chemotherapy in patients with non-small-cell lung cancer not responding to previous chemotherapy. Am J Clin Oncol. 2003;26(6):567-570.

18. Hainsworth JD, Burris HA 3rd, Litchy S, et al. Gemcitabine and vinorelbine in the second-line treatment of nonsmall cell lung carcinoma patients: a minnie pearl cancer research network phase II trial. Cancer. 2000;88(6):1353-1358.

19. Han JY, Lee DH, Song JE, et al. Randomized phase 2 study of irinotecan plus cisplatin versus gemcitabine plus vinorelbine as first-line chemotherapy with second-line crossover in patients with advanced nonsmall cell lung cancer. Cancer. 2008;113(2):388-395.

20. Herbst RS, Khuri FR, Lu C, et al. The novel and effective nonplatinum, nontaxane combination of gemcitabine and vinorelbine in advanced nonsmall cell lung carcinoma: potential for decreased toxicity and combination with biological therapy. Cancer. 2002;95(2):340-353.

21. Juergens R, Brahmer J, Ettinger D. Gemcitabine and vinorelbine in recurrent advanced non-small cell lung cancer: sequence does matter. Cancer Chemother Pharmacol. 2007;59(5):621-629.

22. Kosmas C, Tsavaris N, Panopoulos C, et al. Gemcitabine and vinorelbine as second-line therapy in non-small-cell lung cancer after prior treatment with taxane+platinum-based regimens. Eur J Cancer. 2001; 37(8):972-978.

23. Park YH, Lee JC, Kim CH, Ryoo BY, Kim HT. Gemcitabine and vinorelbine as second-line therapy for non-small cell lung cancer after treatment with paclitaxel plus platinum. Jpn J Clin Oncol. 2004;34(5): 245-249.

24. Pectasides D, Kalofonos HP, Samantas E, et al. An out-patient secondline chemotherapy with gemcitabine and vinorelbine in patients with non-small cell lung cancer previously treated with cisplatin-based chemotherapy. A phase II study of the Hellenic co-operative Oncology Group. Anticancer Res. 2001;21(4B):3005-3010. 
25. Chen YM, Perng RP, Shih JF, Tsai CM, Whang-Peng J. A randomized phase II study of vinorelbine plus gemcitabine with/without cisplatin against inoperable non-small-cell lung cancer previously untreated. Lung Cancer. 2005;47(3):373-380.

26. Esteban E, Fra J, FernandezY, et al. Gemcitabine and vinorelbine (GV) versus cisplatin, gemcitabine and vinorelbine (CGV) as first-line treatment in advanced non small cell lung cancer: results of a prospective randomized phase II study. Invest New Drugs. 2006;24(3):241-248.

27. Greco FA, Spigel DR, Kuzur ME, et al. Paclitaxel/Carboplatin/ gemcitabine versus gemcitabine/vinorelbine in advanced non-small-cell lung cancer: a phase II/III study of the Minnie Pearl Cancer Research Network. Clin Lung Cancer. 2007;8(8):483-487.

28. Laack E, Dickgreber N, Muller T, et al. Randomized phase III study of gemcitabine and vinorelbine versus gemcitabine, vinorelbine, and cisplatin in the treatment of advanced non-small-cell lung cancer: from the German and Swiss Lung Cancer Study Group. J Clin Oncol. 2004; 22(12):2348-2356.

29. Saito H, Nakagawa K, Takeda K, et al. Randomized phase II study of carboplatin-paclitaxel or gemcitabine-vinorelbine in patients with advanced nonsmall cell lung cancer and a performance status of 2: West Japan Thoracic Oncology Group 0004. Am J Clin Oncol. 2012;35(1):58-63.

30. Yamamoto N, Nakagawa K, Uejima H, et al. Randomized phase II study of carboplatin/gemcitabine versus vinorelbine/gemcitabine in patients with advanced nonsmall cell lung cancer: West Japan Thoracic Oncology Group (WJTOG) 0104. Cancer. 2006;107(3): 599-605.

31. Go SI, Lee WS, Lee GW, et al. Gemcitabine plus vinorelbine as the second-line treatment and beyond in elderly patients with platinumpretreated advanced non-small cell lung cancer. Chemotherapy. 2014; 60(4):267-273.

32. Albain KS, Crowley JJ, LeBlanc M, Livingston RB. Survival determinants in extensive-stage non-small-cell lung cancer: the Southwest Oncology Group experience. J Clin Oncol. 1991;9(9):1618-1626.

33. Finkelstein DM, Ettinger DS, Ruckdeschel JC. Long-term survivors in metastatic non-small-cell lung cancer: an Eastern Cooperative Oncology Group Study. J Clin Oncol. 1986;4(5):702-709.
34. Hoang T, Dahlberg SE, Sandler AB, Brahmer JR, Schiller JH, Johnson DH. Prognostic models to predict survival in non-small-cell lung cancer patients treated with first-line paclitaxel and carboplatin with or without bevacizumab. J Thorac Oncol. 2012;7(9):1361-1368.

35. Hoang T, Xu R, Schiller JH, Bonomi P, Johnson DH. Clinical model to predict survival in chemonaive patients with advanced non-small-cell lung cancer treated with third-generation chemotherapy regimens based on eastern cooperative oncology group data. J Clin Oncol. 2005;23(1): 175-183.

36. Paesmans M, Sculier JP, Libert P, et al. Prognostic factors for survival in advanced non-small-cell lung cancer: univariate and multivariate analyses including recursive partitioning and amalgamation algorithms in 1,052 patients. The European Lung Cancer Working Party. J Clin Oncol. 1995;13(5):1221-1230.

37. Martins RG, Reynolds CH, Riely GJ. Beyond "second-line" in non-small cell lung cancer: therapy and supportive care. Am Soc Clin Oncol Educ Book. 2015;35:e414-e418.

38. Maruyama R, Nishiwaki Y, Tamura T, et al. Phase III study, V-1532 , of gefitinib versus docetaxel in previously treated Japanese patients with non-small-cell lung cancer. J Clin Oncol. 2008;26(26): $4244-4252$.

39. Ohe Y, Ichinose $Y$, Nakagawa K, et al. Efficacy and safety of two doses of pemetrexed supplemented with folic acid and vitamin B12 in previously treated patients with non-small cell lung cancer. Clin Cancer Res. 2008;14(13):4206-4212.

40. Kubota K, Nishiwaki Y, Tamura T, et al. Efficacy and safety of erlotinib monotherapy for Japanese patients with advanced non-small cell lung cancer: a phase II study. J Thorac Oncol. 2008;3(12):1439-1445.

41. Chen YM, Perng RP, Shih JF, Tsai CM, Whang-Peng J. Salvage therapy for Chinese non-small cell lung cancer patients who failed previous chemotherapy. J Thorac Oncol. 2006;1(6):545-550.

42. Song Z, Yu Y, Chen Z, Lu S. Third-line therapy for advanced non-smallcell lung cancer patients: feasible drugs for feasible patients. Med Oncol. 2011;28 Suppl 1:S605-S612.

43. Ying Geng Z, Chang Jiao S, Cui Liu S, et al. Third-line therapy in advanced non-small cell lung cancer. J BUON. 2013;18(4):899-907.
Lung Cancer: Targets and Therapy

\section{Publish your work in this journal}

Lung Cancer: Targets and Therapy is an international, peer-reviewed, open access journal focusing on lung cancer research, identification of therapeutic targets and the optimal use of preventative and integrated treatment interventions to achieve improved outcomes, enhanced survival and quality of life for the cancer patient. Specific topicscoved Cellular research and biomarkers; Identification of biotargets and agents with novel Submit your manuscript here: http://www.dovepress.com/lung-cancer-targets--therapy-journa

\section{Dovepress}

mechanisms of action; Optimal clinical use of existing anticancer agents, including combination therapies; Radiation and surgery; Palliative care; Patient adherence, quality of life, satisfaction; Health economic evaluations. The manuscript management system is completely online and includes a very quick and fair peer-review

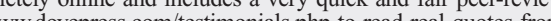
ww.dovepress.com/testimonials.php to read real quotes from published authors. 